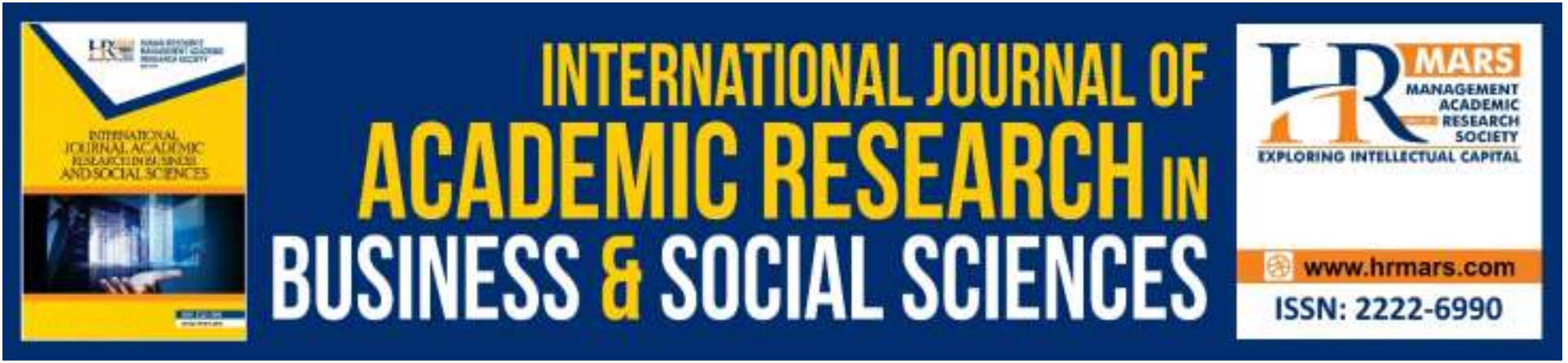

\title{
The Effects of Ownership Structures on Firm Information Asymmetry in Malaysia
}

Josephine Yau Tan Hwang, Goe Zhen Qi, Rosita bt. Hamdan, Audrey Liwan, Jerome Kueh Swee Hui, Mohd Waliuddin bin Mohd Razali and Muhammad Asraf bin Abdullah

To Link this Article: http://dx.doi.org/10.6007/IJARBSS/v9-i9/6384

DOI:10.6007/IJARBSS/v9-i9/6384

Received: 02 August 2019, Revised: 26 August 2019, Accepted: 01 September 2019

Published Online: 27 September 2019

In-Text Citation: (Yau et al., 2019)

To Cite this Article: Yau, J. T. H., Goe, Z. Q., Hamdan, R., Liwan, A., Kueh, J. S. H., Razali, M. W. M., \& Abdullah, M. A. (2019). The Effects of Ownership Structures on Firm Information Asymmetry in Malaysia. International Journal of Academic Research in Business and Social Sciences, 9(9), 950-977.

Copyright: (c) 2019 The Author(s)

Published by Human Resource Management Academic Research Society (www.hrmars.com)

This article is published under the Creative Commons Attribution (CC BY 4.0) license. Anyone may reproduce, distribute, translate and create derivative works of this article (for both commercial and non-commercial purposes), subject to full attribution to the original publication and authors. The full terms of this license may be seen

at: http://creativecommons.org/licences/by/4.0/legalcode

Vol. 9, No. 9, 2019, Pg. 950 - 977

Full Terms \& Conditions of access and use can be found at http://hrmars.com/index.php/pages/detail/publication-ethics 


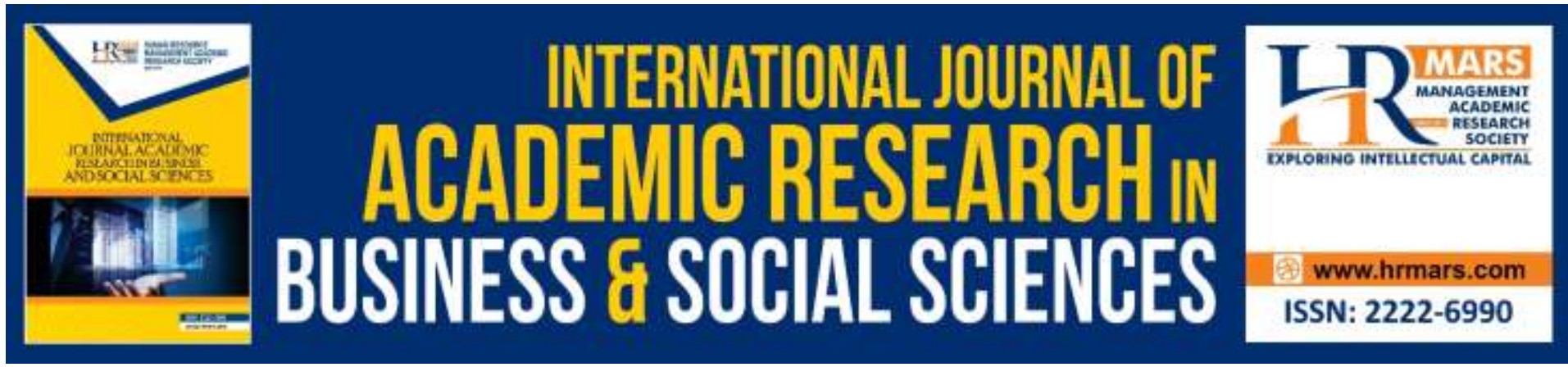

\title{
The Effects of Ownership Structures on Firm Information Asymmetry in Malaysia
}

\author{
Josephine Yau Tan Hwang, Goe Zhen Qi, Rosita bt. Hamdan, \\ Audrey Liwan, Jerome Kueh Swee Hui, Mohd Waliuddin bin \\ Mohd Razali and Muhammad Asraf bin Abdullah \\ Faculty of Economics and Business, Universiti Malaysia Sarawak, 94300 Kota Samarahan, \\ Sarawak, Malaysia \\ Email: ythjosephine@unimas.my
}

\begin{abstract}
This paper presents the relationship between different types of blockholders with information asymmetry in Malaysian firms. To be more specific, this study divides the ownership structures into managerial blockholder, institutional blockholder and individual blockholder and ownership concentration while holding firm size and trading volume as control variables. On the other hand, the stock volatility and bid-ask spread are used as a proxy for information asymmetry. A sample of the top 150 largest public listed firms in term of market capitalisation is chosen from Bursa Malaysia from 2011 to 2015. Panel regression analysis is used to examine the data. The results show managerial blockholders, firm size and trading volume significantly influence information asymmetry. While institutional blockholders, individual blockholders and ownership concentration exhibit no relationship with information asymmetry. The study from this result can be useful for investors and the policymakers in Malaysia as it gives a clearer picture and more understandings on ownership structures and information asymmetry in the Malaysia market.
\end{abstract}

Keywords: Managerial Blockholder, Institutional Blockholder, Individual Blockholder, Ownership Concentration and Information Asymmetry

\section{Introduction}

According to Jensen and Meckling (1976)'s Agency Theory, the managers will not always act in the best interest of shareholders due to conflict of interest. However, there is a remedy to reduce the conflict between manager and shareholders, which aligns the interest of managers with shareholders. Based on the theory, it suggested that whenever there is managerial ownership, the interests of shareholders and managerial block holders are aligned. Nevertheless, Jensen and Meckling further pointed out the expropriate wealth of minority shareholders by the block holders, where the large shareholdings of the share will lead to an increase in incentive to take advantage of small shareholders. Hence, it can be concluded that managerial ownership does reduce agency cost, but at the same time, it also increases the conflict with minority shareholders. 
This raised another question of does the other type of block holders have the same effect on the information asymmetry. In some firm, the shares are owned by solely outsider or managers (the agents). Generally, in these firms, the investors rely on the information in annual report or any voluntary disclosure report to assess the performance of companies. However, it is believed that there is some portion of investors or shareholders have access to internal information due to their large shareholdings and this paper identify them as blockholders. In this study, the existence of large investors such as institutional investors, family investors and individual investors are hypothesised to create or increase information asymmetry due to their higher incentives to gather information and more access to information. This can significantly affect the price of the stock in the market since whenever there is an information asymmetry between those well-informed investors and minority investors, the price will be distorted. It is believed that the large shareholders will use the 'private information' to make a profit by expropriation.

Then, the impact of ownership concentration is also included in this study to give an overall picture of how the dispersion of ownership structure affects the information asymmetry. Besides that, ownership concentration also important as two firms might have an equal percentage of share held by blockholders but different in the concentration of shares for block holders. This is same as the concept of mean and variance. An example would be both $A$ and $B$ firm have $70 \%$ of share held by blockholders, but in firm $A, 70 \%$ share belongs to only one person while in firm $B$ the $70 \%$ is equally distributed among five shareholders. Although both firms having $70 \%$ of blockholder, yet the ownership concentration is believed will have a different impact on firm A and B. Hence besides looking and the different type of ownership structures, this paper also examines the effects of ownership concentration towards firm information asymmetry. In short, this paper intends to answer the following questions. Firstly, what is the relationship between the managerial blockholders and the information asymmetry level? Secondly, whether there is a relationship between institutional blockholders and the information asymmetry? Thirdly, does individual blockholders affect a firm's information asymmetry? And what are the effects of ownership concentration towards firm's information asymmetry?

\section{Background of Study}

Information asymmetry can happen when one party have more or advantage information than another party. In the Modigliani and Miller paper (1963), the concept of information symmetry was introduced where in a perfect market, the information of company and investor are equally the same. Thus, when there is information asymmetry, this assumption will be failed to hold, and the stock price will be distorted. The presence of information asymmetry on stock will cause the difference of value perceived between well informed and retail investor. In equity market, the most common information asymmetry is insider trading where the employees or directors have private information and make profit by utilizing the information. Although insider trading is not allowed all market around the world, but this is still rampant in the market.

The information asymmetry can further categorise into two types, which are moral hazard and adverse selection. In 2001, George Akerlof, Michael Spence and Joseph Stiglitz were 
awarded the Nobel Price Award which gives recognition for the theory of information asymmetry in the market. The adverse selection is referring to a situation where both parties are going into an agreement, and one of them have more information than another. While moral hazard refers to the situation where information asymmetry happened after the agreement. In finance, the information asymmetry happened on both between company and investor and between investor and investor. It is believed that information asymmetry is one of the causes for subprime mortgage crisis in US 2008 due to information asymmetry problem between borrowers and brokers, aggregators and rating agencies, and investors and issuers (FDIC, 2008). The subprime mortgage was securitized into a chain of complex financial product, such as mortgage-backed securities, collateralized debt obligation, and credit default swap. This has caused the extremely high information asymmetry for investor due to the high complexity of products. As a result, the lack of information leads most of the investor to rely solely on the assessment of rating agencies, which in turn causes the bubbles in the financial market.

In Malaysia, the insider trading is regulated by the securities commission under section 188 Capital Market, and Services Act (Amendment) 2015 and any person who found guilty will face imprisonment up to ten years and a fine at least RM 1 million (SCM, 2016). Figure 1 shows the historical data for insider trading cases in Malaysia. From Figure 1, the insider cases had the highest proportion (30\%) in ongoing court cases in 2015, and this proportion keeps increasing to $49 \%$ in 2018. In an interview between the Star Media reporter and a senior securities analyst in the stock market, the analyst said that insider trading not uncommon in Malaysia but not many had been caught and prosecuted (Ho, 2016). Hence, it was believed that the cases that are brought to the court are merely the tip of the iceberg, and there is still many insider trading happened in Malaysia stock market. According to Securities Commission Malaysia 2015 report, most of the cases were related to the directors with the purpose of causing wrongful loss.

Figure 1. Ongoing Court Cases of Malaysia listed firms for 2015 by the Nature of Cases

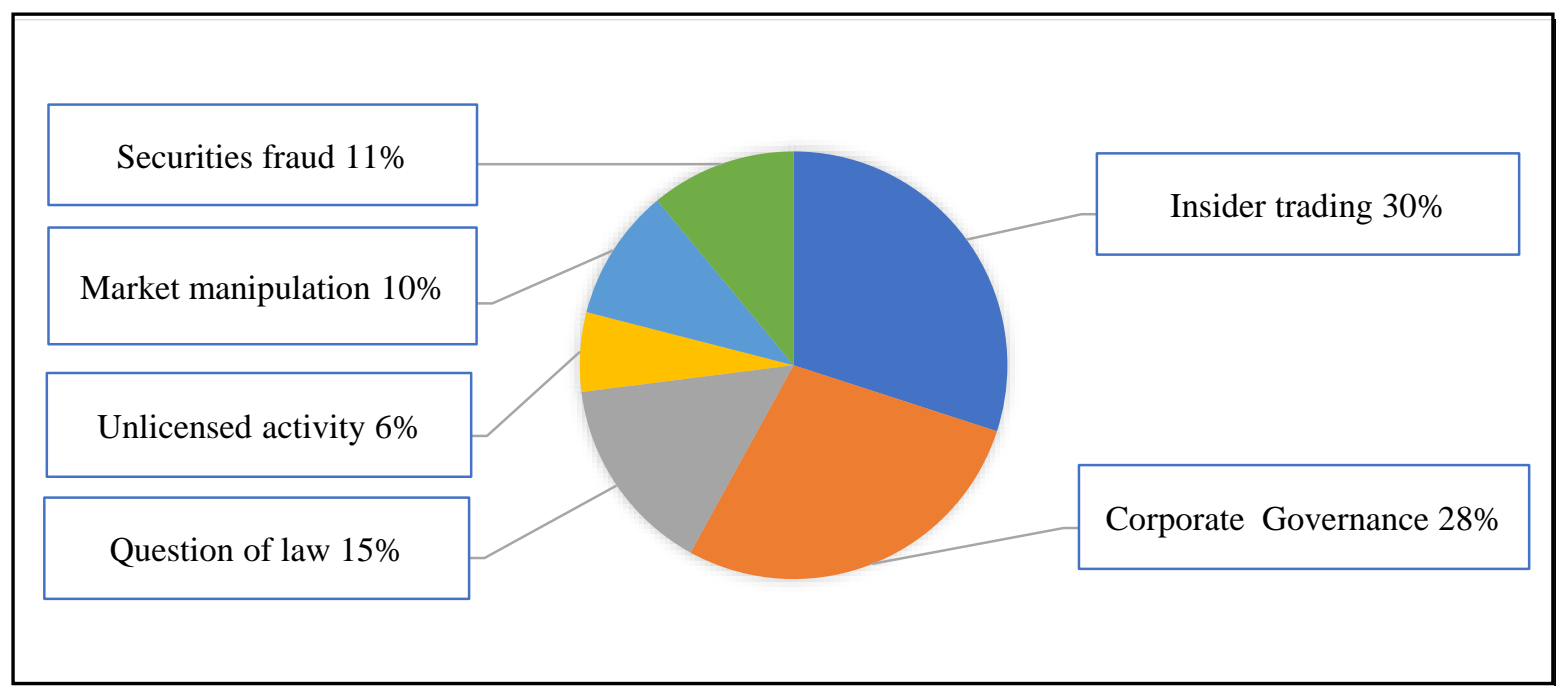

Source: from Annual Report 2015 by the Securities Commission of Malaysia 
This statistic implied that there is an existence of information asymmetry between directors and minority shareholders in Malaysia. Hence, this induces the insider trading act in the market. According to Kadir and Muhhamad (2012), director and executive have a higher tendency to commit this offence due to their higher control of the company and better position to acquire advantageous information. This provided an intriguing background for this study.

In Malaysia, there are no restrictions on substantial shareholders, but it is mandatory for firms to disclose shareholding of 5\% or above under Section 69 of the Malaysia Companies Act 1965 (SSM, 2016). Hence, the cutoff point for block holders in this study is defined as $5 \%$. According to the listing criteria of Bursa Malaysia, for a company to be listed, it must have at least $25 \%$ of public spread based of company equity with a minimum 1000 shareholders that have no less than 100 shares each (Bursa Malaysia, 2016). Based on these criteria, the public listed companies might have a different concentration in term of ownership depending on its capital issued. On top of that, the company also need to allocate $50 \%$ of the public spread to the Bumiputera investor on best effort (Bursa Malaysia, 2016).

In conclusion, the ownership structure of public listed companies is different among each other based on the shares issued by the firm. After being listed, all public listed firms have the obligation to disclose the annual report correctly for the stakeholders. These rules and regulation are mostly mandatory while there is also governance code that is not linked with law, which only serves as the code or recommendation such as Malaysia Code of Corporate Governance 2012.

When a company become publicly listed, the ownership of the company become more dispersed compared to private-held companies. For a public company, the ownership structure can be defined as the distribution of equities or the identity of the owners. According to Mintzberg (1983), ownership structure can be divided based on two perspectives of ownership, which are involvement and concentration. Involvement refers to the degree of influencing between the owners and the firm actions. While concentration refers to the dispersion of the stock held by the stockholders, besides that, the ownership structure can be further categorized into families, states, institutional and widely-held corporation. Family ownership means the firm's largest shareholder is held by family members and at the same time, the family is the largest vote holders, for example, Genting Group Bhd and IOI Group Bhd. In Malaysia, states ownership is usually referring to Government Linked Companies (GLC). The institutional ownership is the same as the family ownership except for the share is owned by an institute. For the widely-held corporation, the shares are held by minority shareholders who do not have any owner with significant control rights. In the Malaysia context, blockholder can be defined as any entity or individual that possess $5 \%$ or above share for a company.

According to Amran and Ahmad (2013), most of the firms in Malaysia have a high concentration of ownership with government, individuals and family. Under the government policy, in 2013, Government Linked Companies (GLC) account for 36\% of the market capitalisation of Bursa Saham Malaysia (Asian Development Bank, 2013). Tam and Tan's (2007) study shown that Malaysian firms have a high concentration of ownership by 
presenting the distribution of sample companies in each type of ownership in Malaysia in 1998; individual ownership concentration of $38.45 \%$, state ownership $55.23 \%$, foreign ownership 50.46\%, and trust fund 53.69\%. Paramanantham, Ting, and Kweh (2018) studied the top 100 PLCs in Malaysian firms' ownership concentration and their debt structure; they found that there is an average of $41.50 \%$ concentrated ownership of largest shareholder and $54.90 \%$ of average concentrated ownership of five largest shareholders.

This study aims to examine the relationship between ownership structure and information asymmetry in Malaysia. Although there were many researchers studied on the ownership structure in Malaysia, but only a few of them explored the relationship between information asymmetry and ownership structure. Despite that, there are many studies ${ }^{1}$ conducted outside of Malaysia. Malaysia is a country where the firms exhibit a unique pattern in ownership due to the peculiar culture of eastern people and the policy of government Malaysia. The high ownership concentration in Malaysia provides an exciting backdrop for this research.

In previous studies ${ }^{2}$, the large shareholding, especially institutional investors, were proven to have more prominent roles in monitoring the companies and improved the corporate governance of the company. However, at the same time, there are also theory and empirical studies $^{3}$ that suggested there was a conflict between these large shareholders and minority shareholders. According to Kidwell and Nygaard (2010), agency conflict can be categorised into vertical and horizontal. The blockholders was expected to decrease the vertical agency conflict but increase the horizontal conflict. Hence, the net effects are unknown and vague. As corporate governance increase, a firm should have more transparency and more disclosure of quality information. The question here is raised, which type of shareholding have larger impact?. Does the increase in blockholders result decrease the information asymmetry due to better corporate governance? Or alternatively, the large blockholders will lead to more private information and increase the information asymmetry?

According to agency theory, the managerial ownership reduces the agency cost but at the same time its incentive to expropriate on the minority shareholders increases due to the insider information which accessible due to its power of manager. If there is a positive relationship between managerial blockholders and information asymmetry, is the effects same for other types of blockholders? In this study, the diverse type of blockholders is believed to exhibit different impacts on information asymmetry compared to managerial ownership. Hence, this study intended to specify the effect of institutional ownership and individual ownership on information asymmetry.

\footnotetext{
${ }^{1}$ As example; Kothare (1997), Kini \& Mian (1995), Mishra, Heide \& Cort (1998) for US studies. Xiao \& Yuan (2007), Yong et al (2015) and Gul, Kim \& Qiu (2010) for China market, and Chen \& Ho (2000) and Mak \& Li (2001) for Singapore market.

2 The studies that support the institutional blockholders increased information asymmetry by better corporate governance are Gillan \& Starks (2003), Mckinnon \& Dalimunthe (1993) and Mccahery, Sautner \& Starks (2016)

3 The studies that found the presence of agency conflict between large shareholder and minority shareholders are Heflin and Shaw (2000), Omari et al (2013) and Ho et al (2014) 
There are two arguments for the relationship of institutional blockholders and information asymmetry based on the scholars. The first paradigm is the greater institutional ownership is expected to reduce the information asymmetry as the firm with higher institutional ownership will attract more financial analyst following. This, in turn causing more public information being disseminated and lower the cost of acquiring information. While, the second paradigm is based on the adverse selection theory and self-interest hypothesis where the institutional investors were deemed to have more expertise, connection with insider and hence higher access to the information.

For the individual blockholders, the relationship is uncertain as not many studies have a focus on this type of blockholders. The individual shareholder might have access or no access to advantageous information. Hence, this provides an interesting point for this study. The ambiguous relationship between ownership structure and information asymmetry is clarified in this paper. In term of Malaysia context, the ambiguity impact of ownership structure further increases due to the different environment with other countries. It is vital to investigate the effects of ownership structure as Malaysian firms have high ownership concentration.

\section{Literature Review}

The agency theory was first proposed by Jensen and Meckling 1976. In the paper, they introduced the agency cost which was identified as the sum of monitor expenditures incurred by the principal, the bonding expenditures by the agency and the residual lost (Jensen \& Meckling, 1976). In other words, agency cost is the cost that arises due to the conflict of interest. In the paper, the managerial ownership concentration was found to be negatively related to the expropriation of minority shareholders. In 1983, Fama and Jensen further explored the agency theory to the extent of separation of ownership and control. The agency problem can be resolved by aligning the interest between manager and shareholders through the pay for performance compensation method by rewarding share options. Jensen and Murphy (1990) agreed that stock options tied the compensation of manager to the value of shareholders. Overall, this theory assumes people are opportunistic, materialistic and selfinterest.

Adverse Selection is a case of information asymmetry that happened when one party has more relevant information than the other party and put another party at a disadvantage position. The most prominent paper for this theory is the paper of George Akeloft (1970) "The Market for Lemon". The empirical of study then was conducted by Dalhby (1992), and Puelz and Snow (1994) show the evidence of the presence of adverse selection in the market. According to Easley and O'hara (1987), when there is adverse selection, informed traders are more willing to trade at the larger size at any given size, which gives an insight for adverse selection in the stock market. Attig, Fong, Gadhoum and Lang et al. (2006) found that the stocks with greater separation of ultimate control and ownership have greater adverse selection problem.

Efficient Market Hypothesis (EMH) was first proposed by the Eugene Fama in 1965, where $\mathrm{EMH}$ suggested that there is no information asymmetry and the prices in the financial market reflect the information. Although this theory faces a lot of critics as many real-life examples 
show that it is possible to beat the market and earn an above-average return, which indicates the market is not efficient. Nevertheless, it is still useful and supported by many scholars. The EMH can be in several forms which are weak, semi-strong and strong. In the weak form efficient market, the current price of stocks only contains the past information. While in the semi-strong efficient market, the current prices contain all information that publicly available. For the strong form, the prices fully reflect all the information include private information. According to $\mathrm{EMH}$ theory, since all the information are reflecting in the prices and hence no one can make excessive profits over time. In Malaysia, the empirical studies have been conducted by Nassir et al. (1993), Lim (2008), Munir and Mansur (2009) and Ling and Rahim (2006). In these studies, the weak form of market efficiency was found in Malaysia stock market. Hence, if there is an efficient market presence in Malaysia, the ownership structure will have no effects on the information asymmetry since the prices fully reflect its true value.

Information asymmetry is the degree of information shared by investor and large shareholder. Many factors can affect the information asymmetry level in the market, such as corporate governance, disclosure quality, regulation of the country, managers' disclosure decision (Healey \& Palepu, 2001). The information asymmetry will cause the mispricing of the stock price in the market, which in turn, it might cause the slow development of the country. In the paper of Beltran and Thomas (2010), the information asymmetry was identified as one the main cause in market failure. Hence information asymmetry needs to be monitored by the government in order to ensure the efficiency of the stock market. The high level of information asymmetry will affect the confidence of investor in making the transaction as it causes fear that the informative party will benefit at their expenses.

In the previous study, information asymmetry has been related to many variables, especially corporate governance, insider trading, voluntary disclosure and cost of capital. According to Glosten and Milgrom (1985), the high information asymmetry would drive the market to widen its bid-ask spread. This gave literature about the informative of transactions price regarding the information asymmetry. Besides that, the increase in information asymmetry in the market also expects to decrease the liquidity of the stock. This is supported by Petersen and Plenborg (2006), where the empirical result shows that corporate information reduces information asymmetry and then increasing investors' confidence and hence, the number of transactions.

Ownership structure can divide into several categories based on the previous studies which are managerial (Coles, Lemmon \& Meschke, 2012; Jensen \& Meckling, 1976; Chen \& Yu, 2012), institutional (Xu \& Wang, 1999; Gordon \& Pound, 1993), government (Mak \& Li, 2001), individual, family (Claessens, Djankov \& Lang, 2000; La Porta, Lopez-de-Silanes \& Shleifer, 1999). Ownership structure has an impact on the firms as it affects corporate governance, value, performance and management behaviour. In the Agency Theory proposed by Jensen and Meckling (1983), the ownership structure affects the conflict of interest between managers and shareholders. Also, there is a relationship between firm performance and the ownership structure. Lemmons and Lins (2003) suggest that firms with dispersed ownership are underperforming due to the expropriation from the management during the hard times of the economy. Hence, based on these previous researches, the blockholders have an impact that cannot be neglected in the financial market. 
For the ownership concentration, it was believed that the increase in ownership concentration would reduce the agency cost hugely due to the incentives of owners to monitor the performance of the principal (Koke, 1999). However, the large shareholding may expropriate private benefits at the expense of other shareholders. Besides that, the large shareholding might control the decision of the firm according to their own interest, goal and preferences which raised to another agency problem.

In summary, the agency theory, adverse selection and efficient market hypothesis have been tested empirically and theoretically. Hence, it is proven presence in many markets and when there is an information asymmetry the more informative party will take advantage of the private information. Different countries have different ownership structure and concentration based on the uniqueness of the country. For example, the ownership structure of Japanese firm is different from other countries as most of the firms are affiliated with its suppliers and members of the business group (keiretsu) (Lee \& O'neill, 2003). According to Fan \& Wong (2002), Malaysia has the third highest ownership concentration in the East Asian countries, which on average $30.73 \%$. Hence, this study intends to investigate the effect of high ownership concentration and the blockholders structure in Malaysia.

\section{Hypotheses Development}

\section{Managerial Ownership and Information Asymmetry}

Finnerty (1976) tested against the Efficient Market Hypothesis (EMH) by determining the information asymmetry between insider and outsider. Finnerty suggested that insider can always earn above average return in buying securities holding other variables constant. In its conclusion, there was an information asymmetry between insider holdings and outsider and the market was not strongly efficient. Sheyhun (1985) provided the first empirical test between the bid-ask spread and superior return of informative trading. The result of the study showed that an insider could have more information about price changes and make informed trading to gain profit. Besides that, the study also indicated that insider ownership possesses more information as managerial owners have more access and incentives than both insider executives and shareholders.

Chiang et al. (1988) investigated the relationship between insider ownership and information asymmetry. Based on the result from the study, insider blockholder was said to have an impact on the information asymmetry which proxy by the bid-ask spread. Similar research also has been done by Kini and Mian (1995) by using bid-ask spread as measurement for information asymmetry; their regression model result showed there was a negative relation between information asymmetry and insider holdings. Besides, the study also found that larger firm tends to have a higher proportion of institutional blockholder than the insider blockholder while the small firm exhibits the opposite.

On the other hand, Zhou (2011) tested the effects of managerial ownership on liquidity and information asymmetry. The result of the study shows insider ownership was positively correlated with spread after controlling several variables. Besides that, the result also indicated that higher insider ownership had a significant positive relationship with trade informativeness. 
In Malaysia, the literature on this field was conducted by Mustapha and Ahmad (2011), which the agency theory and ownership structure were tested in Malaysia sample. By using the data from the questionnaire and annual report, the regression model was run to examine the relationship. The result suggested that when the managerial ownership increases the agency cost, and the information asymmetry was lowered as the interest are aligned. Hence, based on the above reviews, we hypothesised our first hypothesis as follows:

$\mathrm{H}_{1}$ : There is a significant relationship between managerial blockholder and information asymmetry.

\section{Institutional Ownership and Information Asymmetry}

Jennings, Schnatterly and Seguin (2002) examined the relationship between institutional ownership and information asymmetry; the institutional was further categorised into commercial bank, insurance companies, investment companies, independent advisers and others. Based on the result, the institutional ownership was negatively related to the bid-ask spread with different significant level for each type of institutional. In 2007, Rubin conducted a study to identify the relationship between liquidity and stock ownership which focus on testing whether the informed shareholders possess more information compared to uninformed, and then information asymmetry arises, and stock liquidity reduces. In its findings, it found out that by using two side relation liquidity (proxy for information asymmetry) increase (decrease) when the institutional ownership concentration increase (decrease). Hence, there was a positive correlation between both variables.

Wang and Zhang (2009) further break down institutional investor into transient institutional and the dedicated one. Transient institutional blockholders were those who do not participate in the firm's corporate governance and for the dedicated one behave oppositely. In this study, the asymmetry information was not based on stock market but debt. The result showed when there was an increase in transient owners in a firm; the credit spread narrow due to the lower information asymmetry. On the contrary, an increase in dedicated ownership resulted in the high information asymmetry with wider credit spread. This paper contributed to literature as it breakdown the types of institutional ownership and provided the information asymmetry in the debt market. Besides that, this paper also provided literature on using credit spread to measure information asymmetry.

Jiang, Habib and Hu (2009) also studied the relationship between institutional ownership and information asymmetry and the institutional is divided into three categories: Financial institution-controlled, Management-controlled and Government or other companycontrolled. The result from the study showed the high ownership concentration in financial institutional will lead to low information asymmetry. On the contrary, the government and managerial ownership concentration will decrease the information asymmetry. The findings provided literature on the country with weak minority shareholder protection. In a recent study, Shiri, Salehi and Radbon (2016) also determined the ownership structure's impact on information asymmetry and found that information asymmetry was high when the firm has a major owner and institutional blockholder. The result of the study was claimed to be consistent with the self-interest hypothesis. 
In Malaysia, Ali, Salleh and Hassan (2010) found that the institutional blockholder harms earnings management, which proxy by the discretionary accruals. This empirical evidence the agency conflict was reduced when the institutional blockholders increase at the same time the agency cost was lowered. In short, they concluded that information asymmetry should be decreased when the institutional ownership increase. Hence, hypothesis 2 is designed as:

$\mathrm{H}_{2}$ : There is a significant relationship between institutional blockholder and information asymmetry.

\section{Individual Ownership and Information Asymmetry}

Zeckhauser et al. (1990) discussed the relationship between large shareholding and corporate performance. The result supported that large shareholder able to help in reducing an informational problem in capital markets by monitoring management. Yeo et al. (2002) examined the ownership structure and informativeness of earnings and found a strong positive relationship between external unrelated blockholdings and the informativeness of earnings. Hence, this implied that outsider blockholders could act as a monitor and reduce information asymmetry between manager and investor. Furthermore, Firmuc et al. (2005) studied insider trading, new release and ownership concentration in the UK market. From the result, it provides strong support which monitoring by blockholders reduces the information value of directors' purchases. In the justification of this paper, the information gap was reduced when there is a presence of families or individual blockholder. In addition, in the findings, the evidence of the outside shareholders has a relationship on abnormal return was provided.

Brockman et al. (2009) studied different type of blockholders. After controlling the market, firm-level and industry factors, the outsider blockholders were found to have a positive relationship with information asymmetry which proxy by the probability of informed trading. A similar study also conducted by Samaha and Dahawy (2016), where the factor affecting disclosure transparency was identified. In the paper, blockholder was hypothesised to have an inverse relationship with the disclosure of transparency for firms. The findings showed that the blockholders were statistically significant and negative related to the disclosure of a company. It showed that there was a relationship between blockholders and information asymmetry. Therefore, hypothesis 3 is developed as follows:

$\mathrm{H}_{3}$ : There is a significant relationship between individual blockholder and information asymmetry.

\section{Ownership Concentration and Information Asymmetry}

Heflin and Shaw (2000) believed that large ownership concentration would have more access to private information via their monitoring role in firms. In its empirical result, the ownership concentration was positively related to both relative spread and effective spread. To be more accurate, the component of adverse selection was separate from the spread, and the relationship is the same as the previous model. Furthermore, the findings also showed that non-manager and manager owners have the same positive relationship with information asymmetry. Fan and Wong (2002) also conducted a study in determining the relationship 
between ownership structure and informativeness in earnings. The argument in this study was whether the ownership concentration affects informativeness by self-interest hypothesis or entrenchment effect. The results showed the high ownership concentration, and large separation of ownership and control weaken the informativeness of investor. Moreover, Attig et al. (2006) suggested that the larger the difference between ultimate control and ultimate ownership, the greater the information asymmetry. Omari, Fazlzadeh and Nahidi (2013) employed Herfindahl index to measure ownership concentration and found that ownership concentration had a positive relationship with information asymmetry no matter the firm is low voluntary disclosure or not.

In Malaysia, there was more researcher examine the relationship between ownership concentration and voluntary disclosure. Ho and Taylor (2014) examined corporate governance, ownership concentration and information asymmetry. Ownership concentration was found to have a statistically significant positive relationship with the voluntary disclosure, and information asymmetry was decreased with voluntary disclosure. Hence, we constructed hypothesis 4 as follows:

$\mathrm{H}_{4}$ : There is a significant relationship between ownership concentration and information asymmetry.

\section{Firm Size, Trading Volume and Information Asymmetry}

Firm size gives an idea of how big is the firm. Firm size is a crucial element in finance as most of the components in corporate finance seem related with the firm size such as CEO compensation (Jensen and Murphy, 1990), stock return (Fama and French, 1992), capital structure (Barclay and Smith, 1995) and others. Firm size can be measured by market-to-book ratio, sales, number of employees and total asset. According to Sheyhun (1986), firm size does impact the firm's information asymmetry. Leuz and Verrecchi (2000) and Petersen and Plenborg (2006) also found that firm size was negatively correlated with information asymmetry. Hence, firm size is included as one of the explanatory variables in this study. It is arguing that smaller firms tend to have more internal information and less informed investor hence lead to greater information asymmetry.

Trading volume is the total number of shares traded in the given time of period. The trading volume is informative as the investor or financial analyst can get some insight based on the trading volume. This was empirically studied by Karpoff 1987 (prices change and trading volume), Lee and Swaminathan, (2000) (price momentum and trading volume) and others. Furthermore, the technical analysis also includes the trading volume as one of the factors to identify the movement of the stock price. Kim and Verrecchia (1991) investigated the relationship between price and volume reactions to a public announcement. By using event study, the difference in precision/information among investor was an important factor influencing volume trading volume. Trading volume is closely linked with the information asymmetry because as the informed trader try to exploit the private information in hand in trading volume increase. According to Boujelbene and Besbes (2012), the trading volume was identified as one of the determinants of information asymmetry. Suominen (2011) suggested that the trading of informed investor in the market will noticed by other investors, which in turn affect the uninformed behaviour. Besides that, when there is high probability of private 
information, the speculators were attracted, and number of trading will increase. Hence, this gives an implication that the trading volume was related to the information asymmetry. Therefore, hypothesis 5 and 6 are designed as:

$\mathrm{H}_{5}$ : There is a significant relationship between firm size and information asymmetry.

$\mathrm{H}_{6}$ : There is a significant relationship between trading volume and information asymmetry.

\section{Data and Methodology}

A sample of the top 150 largest public listed firms in term of market capitalisation is chosen from Bursa Malaysia from 2011 to 2015. The data are extracted from Thomson Reuters Datastream. The data of the shareholding percentage by different types of blockholders and the ownership concentration were manually collected from the respective firms' annual reports. Our research design is developed as in Figure 2.

Figure 2. Conceptual Framework for this study

\begin{tabular}{|l|l|l|}
\hline \multicolumn{1}{|l|}{ Independent Variables } & Dependent Variable \\
\hline Managerial Blockholder & \\
Institutional Blockholder & \\
Individual Blockholder & \\
Ownership Concentration & \\
Firm Size & \\
\hline
\end{tabular}

\section{Data Description \\ Information Asymmetry}

The idea of using bid-ask spread to measure information asymmetry was first proposed by Bahegot in 1971. Subsequently, this proxy has been widely used by other researchers (such as Lin, Sanger \& Booth, 1995; Ness et al., 2001). There is also another proxy in term of corporate finance used in measuring the information asymmetry, such as volatility of stock price, trading volume and others. This is also supported by many papers such as models of Glosten and Harris (1988), Kyle (1985), and Easley and O'Hara (1987) show asymmetric information is captured in the price impact. Volatility measurement is commonly used as the proxy for information asymmetry. According to the study of Glosten and Milgrom (1985), the bid-ask spread can be used to estimate the information asymmetry in the market. However, they also mentioned that bid-ask spread is a noisy proxy, as there might even drive by many other factors. Hence, the volatility of stocks price is used as the main proxy for the information asymmetry while bid-ask spread is used at the robustness test. The formula of each proxy for information asymmetry is shown as below: 
Stock Volatility $=\frac{\sum \text { daily vola tility }}{\text { number of days }}$
Bid - Ask Spread $=\frac{\text { Ask }- \text { Bid }}{(\text { Ask }+ \text { Bid }) / 2} \times 100 \%$

\section{Identities of Blockholders}

The identity of blockholder is one of the independent variables for this study, which is managerial, institutional and individual. The shareholdings that above $5 \%$ is considered as a blockholder for this study because, in Malaysia, any shareholder with $5 \%$ holdings will need to be disclosed by firms in the annual report. The calculation for these three variables is the total percentage of shares held by the different types of blockholder. In the previous studies, this measurement is mostly used to measure the different types of ownership; for example, McConnel (1990) and Gedajlovic and Shapiro (2002). The calculation for this variable is shown below:

$$
\begin{aligned}
& f(x)=\sum \text { shares in } \% \text { by } x \\
& \text { Whereby, } \quad=\text { identity of blockholder } \\
& \begin{array}{ll}
\mathrm{x} & =\text { percentage of shares }
\end{array}
\end{aligned}
$$

\section{Ownership Concentration}

In term of ownership concentration, the concentration ratio was used, which the ratio was calculated by adding up the percentage of share held by the largest $\mathrm{N}$ number of owners. It was applied in the paper of Shiri et al. (2016), Tam and Tan (2007). However, there are some researchers argue that using the concentration ratio is not a good measurement as it ignores the holding distribution and wrongly assumes. According to Prigge (2007), the increase of owner's shares from $48 \%$ to $52 \%$ is not as same as an increase of $84 \%$ of shares to $88 \%$ of shares. Hence, when the concentration ratio is used, the linearity of shareholder's voting power and its influence is wrong because $50 \%$ is enough for a shareholder to become the majority shareholders.

In the paper of Demsetz and Lehn (1985), the Herfindahl index was used to represent the ownership concentration. Although the Herfindahl index also has been used by many researchers in measuring the ownership concentration, it is less preferable and common due to its complexity. According to Soboleva (2009), the Herfindahl index was a better measurement than normal concentration ratio as it can include the residual of shares distribution and linearity of voting power. The Herfindahl index is more accurate compared to the concentration ratio due to its consideration of share distribution and linearity (Goergen \& Renneboog, 2001). The formula for Herfindahl index was calculated as sum of squared ownership shares by $\mathrm{N}$ number of largest investor.

Herfindahl Index $=\sum\left(\mathrm{x}_{1}^{2}+x_{2}^{2}+x_{3}^{2}+x_{4}^{2}+x_{5}^{2}\right)$

Whereby,

$\mathrm{x} \quad=$ the percentage of share held by the $\mathrm{n}$ largest blockholders 


\section{Control Variables: Firm Size and Trading Volume}

According to Shalit and Sankar (1997), there are many measurements for firm size and the choices of proxy should be made according to the purpose of the study. Example, if the study is about the advertising and firm size, then sales might be more appropriate compared to the number of employee or firm's assets. In the finance studies, the firm size is usually measured by using the total assets reported in accounting. In the study of Shiri et al. (2016) and Ettredge, Johnstone, Stone and Wang, (2011) firm size is measured by using the total asset of the company. In the study of Lo and Wang (2000), the trading volume can be measured by using shares traded, dollar traded, number of transaction and turnover. In the past papers that studied the relationship between information asymmetry and trading volume, the trading volume of shares is used as measurement for trading volumes, such as Atkins and Dyl (1997) and Lee and Swaminathan (2000). The formula for our control variables are shown as below:

Firm size $\quad=$ Total assets for the financial year ended at $\mathrm{t}$

Trading volume $=\frac{\text { Trading volume }}{\text { Number of days }}$

\section{Empirical Model}

Based on the conceptual framework constructed by using theory, the dependent variable is hypothesised to correlated to the dependent variables. Hence, the function of information asymmetry can be expressed as:

$f(x)=\int\left[\begin{array}{l}\text { managerial blockholde } \mathrm{r} \text {, institutio nal blockholde } \mathrm{r} \text {, individual } \\ \text { blockholde } \mathrm{r} \text {, ownership concentration, trading volume, firm size }\end{array}\right]$

Therefore, the estimation model is expressed as below:

$\mathrm{IA}_{\mathrm{it}}=\alpha_{i t}+\beta_{1}$ MAN $_{i t}+\beta_{2}$ INSTI $_{i t}+\beta_{3} I_{N D I_{i t}}+\beta_{4}$ OCHI $_{i t}+\beta_{5}$ FSIZE $_{i t}+\beta_{6} T V A_{i t}+\varepsilon$ Whereby,

IA = Information Asymmetry; proxy by Stock Volatility (VOL) and Bid-ask spread (BAS)

MAN = Shares held by managerial blockholders

INSTI = Shares held by institutional blockholders

INDIV = Shares held by individual blockholders

$\mathrm{OCHI}=$ Ownership concentration (Herfindahl index)

FSIZE = Firm size (natural logarithm of total assets)

TVA = Trading volume

$\varepsilon \quad=$ Error term

This study employed descriptive statistics, Pearson correlation coefficient and multiple regression analysis to examine the data. For panel regression analysis, Breusch-Pagan Lagrangian Multiplier Test has been conducted to determine whether Pooled OLS regression should be used or random effects and Hausman Test also been performed to choose between fixed or random-effects model. Besides, diagnostic test also been carried out, such as autocorrelation test, Heteroscedasticsity test, and multicollinearity analysis. 


\section{Result and Findings \\ Descriptive Statistics}

This section provides descriptive statistics and summaries for each of the variables used in this empirical study. The mean, standard deviation, minimum value and maximum value for each variable is shown in Table 1. Based on the table, volatility's mean is 0.017 with a minimum value of 0.004 and a maximum value of 0.2412 while the mean of bid-ask spread is 0.008853 , with minimum is zero and maximum of 0.26415 . In addition, the standard deviation of volatility and bid-ask spread is $1.26 \%$ and $0.01671 \%$ respectively.

Table 1. Summary Statistics

\begin{tabular}{lrrrr}
\hline Variable & \multicolumn{1}{l}{ Mean } & Std. Dev. & Min & Max \\
& & & & \\
\hline Volatility (VOL) & 0.0170694 & 0.0126444 & 0.004 & 0.2412 \\
Managerial Blockholder (MAN) & 24.7315 & 25.28139 & 0 & 78.31 \\
Institutional Blockholders (INSTI) & 19.9737 & 23.97694 & 0 & 87.31 \\
Individual Blockholders (INDI) & 4.766058 & 15.70531 & 0 & 80.78 \\
Ownership Concentration, Herfindahl index (OCHI) & 2565.213 & 1453.877 & 40.6836 & 6669.785 \\
Trading Volume (TVA) & 500581.7 & 737125.4 & 505.1 & 5756022 \\
Total Asset (FSIZE) & 21499.36 & 67445.6 & 31.224 & 708344.5 \\
Bid Ask Spread (BAS) & 0.008853 & 0.016713 & 0.0000 & 0.264151
\end{tabular}

Meanwhile, the descriptive statistics for managerial blockholders, institutional blockholders, and ownership concentration are summarising into Table 2 in order to make a comparison with the previous study. There are only small changes or differences between the average ownership structures in managerial blockholders in Malaysia. For the institutional and individual ownership, there is a small gap between the past researches and this paper. The differences may arise due to the sampling method, as in this study, the top 150 market capitalisation firms are selected. In large firms, the institutional blockholders tend to be higher and individual blockholders tend to be lower. In overall, Malaysia ownership structure is still dominated by the managerial blockholders and institutional blockholders with average $24.73 \%$ and $19.97 \%$ respectively.

Table 2. The Comparison of Managerial, Institutional, Individual Blockholders with Previous

\begin{tabular}{lcl} 
& Studies in Malaysia \\
\hline Variable & Our Result & Previous Study's Result \\
Managerial Blockholder & & Ghazaili, 2010 \\
Mean & 24.7315 & 21.42 \\
Minimum & 0 & 0 \\
Maximum & 78.31 & 71.71 \\
\hline Institutional Blockholder & & Wahab, Zain, James and Haron, 2009 \\
Mean & 19.9737 & 12.069 \\
Minimum & 0 & 0 \\
Maximum & 87.31 & 90.533 \\
\hline Individual Blockholder & & Ishak and Napier, 2006 \\
Mean & 4.7661 & 9.93 \\
Minimum & 0 & 0 \\
Maximum & 80.78 & 67 \\
\hline
\end{tabular}


For the Herfindahl Index, the mean value is 2565.231 which indicate that the average ownership concentration in Malaysia is high because an above 2000 index number would need at least one blockholder with more than $44.72 \%$ shareholdings to compute. The data for the Herfindahl Index range from 40.683 to 6669.785 . Based on the descriptive statistics, the Herfindahl's standard deviation is high, and thus, the variable need to be transformed by using the log-transformation method, the same transformation also been applied for trading volume and total asset.

\section{Pearson Correlation}

Table 3: Correlation coefficient

\begin{tabular}{|c|c|c|c|c|c|c|c|c|}
\hline & VOL & MAN & INSTI & INDI & FSIZE & TVA & $\mathrm{HI}$ & BAS \\
\hline Volatility (VOL) & 1 & & & & & & & \\
\hline $\begin{array}{l}\text { Managerial Blockholder } \\
\text { (MAN) }\end{array}$ & $0.103^{* * *}$ & 1 & & & & & & \\
\hline $\begin{array}{l}\text { Institutional Blockholders } \\
\text { (INSTI) }\end{array}$ & $0.152^{* * *}$ & $0.555^{* * *}$ & 1 & & & & & \\
\hline Individual Blockholders (INDI) & 0.057 & $0.234^{* * *}$ & $0.171^{* * *}$ & 1 & & & & \\
\hline Firm Size (FSIZE) & $0.238^{* * *}$ & $0.163^{* * *}$ & $0.436^{* * *}$ & $-0.093^{* *}$ & 1 & & & \\
\hline Trading Volume (TVA) & 0.044 & $-0.067^{*}$ & $0.204^{* * *}$ & -0.024 & $0.498^{* * *}$ & 1 & & \\
\hline $\begin{array}{l}\text { Ownership Concentration, } \\
\text { Herfindahl index (OCHI) }\end{array}$ & $-0.092^{* *}$ & $0.106^{* * *}$ & $0.097^{* * *}$ & $0.175^{* * *}$ & 0.013 & $0.313^{* * *}$ & 1 & \\
\hline Bid Ask Spread (BAS) & $0.223^{* * *}$ & $0.064^{*}$ & $0.125^{* * *}$ & $0.131^{* * *}$ & $0.258^{* * *}$ & $0.309^{* * *}$ & $0.071^{*}$ & 1 \\
\hline
\end{tabular}

$*, * *, * *$ denote the correlation is significant at the $10 \%, 5 \%$ and $1 \%$ level respectively.

Table 3 shows that the correlation between the managerial blockholders and volatility (VOL) is it is positive statistically significant at $1 \%$ significant level. While the institutional blockholders is negatively correlated with VOL at $1 \%$ significant level, both results are consistent with the outcome of Rubin (2007) where its paper also found a similar relationship. For the individual blockholders, the correlation is positive insignificant. The Herfindahl index is found significantly negative correlated with VOL at the $5 \%$ significant level. This is consistent with the result of Leaño and Pedraza (2016) and Iskandrani (2016). Our second proxy bid-ask spread found to have a significant positive correlation with ownership concentration. Prior studies also found a positive correlation for both variables such as Rubin (2007) and Chalermchatvichien, Jumroenvong, Jiraporn and Singh (2014).

\section{Multivariate Analysis}

The result shows the main model in this study after accounted for heteroscedasticity problem by using robust standard error method. The stock volatility as a proxy for information asymmetry is regressed against ownership structures which are managerial blockholders, institutional blockholders, individual blockholders and ownership concentration proxy by Herfindahl Index. In addition, the firm-specific factors, such as firm size and trading volume, are included as a control variable. The multiple regression results have been presented in Table 4. 
INTERNATIONAL JOURNAL OF ACADEMIC RESEARCH IN BUSINESS AND SOCIAL SCIENCES Vol. 9, No. 9, September, 2019, E-ISSN: 2222-6990 @ 2019 HRMARS

Table 4. Result of Ownership Structures and Information Asymmetry

\begin{tabular}{|c|c|}
\hline Variables & Stock Volatility (VOL) \\
\hline \multirow{2}{*}{ Constant } & $2.5142^{* *}$ \\
\hline & (1.0379) \\
\hline \multirow{2}{*}{ Managerial Blockholder (MAN) } & $0.5447^{*}$ \\
\hline & (0.3237) \\
\hline \multirow{2}{*}{ Institutional Blockholders (INSTI) } & 0.1149 \\
\hline & (0.2793) \\
\hline \multirow{2}{*}{ Individual Blockholders (INDI) } & 0.5680 \\
\hline & $(0.4766)$ \\
\hline \multirow[t]{2}{*}{ Ownership Concentration, Herfindahl index (OCHI) } & -0.0974 \\
\hline & (0.0917) \\
\hline \multirow{2}{*}{ Firm Size (FSIZE) } & $-0.2423^{* * *}$ \\
\hline & $(0.0346)$ \\
\hline \multirow{2}{*}{ Trading Volume (TVA) } & $0.1442^{* * *}$ \\
\hline & $(0.0422)$ \\
\hline R-squared & 0.109 \\
\hline F-Statistic & 13.35 \\
\hline Prob (F-statistic) & 0.000 \\
\hline No of observations & 717 \\
\hline $\begin{array}{l}\text { Standard errors are reported in parenthese } \\
\text { significance at } 10 \%, 5 \% \text { and } 1 \% \text { levels, resp }\end{array}$ & $\begin{array}{l}d^{*},{ }^{* *},{ }^{* * *} \text { indicate } \\
\text { ely. }\end{array}$ \\
\hline
\end{tabular}

Our result shows a positive relationship between managerial blockholders and information asymmetry at $10 \%$ significant level. The coefficient of 0.5447 indicates that when the managerial blockholders increase by $1 \%$, the volatility for the company stocks increases by $0.0054 \%$. This result is consistent with most of the prior studies, such as Rubin (2007), Brockman and Yan (2009) and Elgouti (2014). Hence, there is evidence that managerial ownership does increase stock price volatility. For the relationship between institutional blockholder and volatility, there is an insignificant positive relationship. The result is inconsistent with previous researches, as most of the studies found a positive and significant result such as Rubin and Smith (2009) and Song and Zheng (2014). Nevertheless, there are also some studies obtained the same result as ours, which found that there is no relation between institutional blockholder and information asymmetry such as Choi, Sami and Zhou (2010) and Tee and Chan (2008).

For the individual blockholders, our result shows that is no relationship between individual blockholders and information asymmetry. The result is consistent with the study done by Alzeaideen and Al_Rawash (2014), where the paper found that there is also an insignificant relationship between these two variables. However, the study of Brockman and Yan (2009) and Azzam (2010) reported a significant positive correlation between individual blockholders and Information asymmetry. Nonetheless, Che (2016) conveyed that individual blockholders is found negatively correlated with volatility. Our result shows that there is an insignificant negative relationship between Herfindahl Index and volatility, which is inconsistent with Prado, Saffi and Sturgess (2013), who found a significant negative relationship. While, most of the past researches suggested that the positive and significant result such as $\mathrm{Ni}$ (2017), Dennis and Strickland (2009), Leuz and Verrecchia (2000) and Brockman and Yan (2009). 
The total assets have a negative impact on volatility as predicted. This result is consistent with most of the prior empirical studies such as Jankensgård and Vilhemson (2016), Ni (2017), and Che (2017). From theoretical studies, it also supported by firm size effects where it suggested that small firm tend to have higher growth and more volatile in stocks prices. Trading volume is positively associated with the volatility. The result is consistent with Harris (1987), Cornell (1981) and Karpoff (1987).

\section{Additional Robustness Test}

For the sensitivity test, we use the bid-ask spread (BAS) as proxy for information asymmetry. The additional test is intended to give an insight on how ownerships affects the information asymmetry because information is not measurable nor observable and volatility do not directly measure the information asymmetry. Hence, it would be more robust if another proxy is used as comparison. Based on the result on additional test, the managerial blockholders exhibits the same positive relationship with information asymmetry, which we use stock volatility as proxy. However, it is not significant for bid-ask spread. For the institutional blockholders, it shows significant negative relationship between institutional blockholder and bid-ask spread, which is different from the insignificant result we observed for stock volatility as proxy. Still, for individual blockholders and ownership concentration, the result obtained is identical for both proxies, which show insignificant impact on information asymmetry. For the control variable, for both proxy, firm, size shows significant negative relationship with information asymmetry. While higher trading volume tends to reduce bid-ask spread and increase stock volatility. In sum, different proxies may yield different results, although both of the proxies are widely used to measure information asymmetry.

Table 5. Additional test for Information asymmetry (proxy by Bid-Ask Spread) and ownership structures.

\begin{tabular}{lr}
\hline VARIABLES & Bid-Ask Spread \\
\hline Constant & $5.3937^{* * *}$ \\
& $(1.7417)$ \\
Managerial Blockholder (MAN) & 0.8923 \\
& $(0.7101)$ \\
Institutional Blockholders (INSTI) & $-0.8135^{*}$ \\
& $(0.4806)$ \\
Individual Blockholders (INDI) & 0.8882 \\
Ownership Concentration, Herfindahl index (OCHI) & $(0.9795)$ \\
& -0.0157 \\
Firm Size (FSIZE) & $10.1708)$ \\
& $-0.2094^{*}$ \\
Trading Volume (TVA) & $(0.1103)$ \\
& $-0.3500^{* * *}$ \\
R-squared & $(0.0579)$ \\
Prob (F-statistic) & 0.2374 \\
Observations & 8.28 \\
\hline Standard errors are reported in parentheses, and ${ }^{*}{ }^{* *}{ }^{* * *}$ indicate &
\end{tabular}




\section{Results Discussion}

Our study found a significant positive relationship between managerial blockholders and information asymmetry. This result supports Agency Theory by Jensen and Meckling (1976) and Adverse Selection Theory by Akerloft (1970). According to Zhou (2011) who found a significant positive relationship in insider and information asymmetry, managerial shareholders do have information advantage compared to outsider shareholders, and by utilising this information, they can make abnormal high profits on the expenses of individual shareholders. Although Berle and Mean (1991) and Jensen and Meckling (1976) suggested that managers with ownership can align the interest between shareholders and reduce information asymmetry by playing monitoring role in firms. Leong and Horwitz (2004) examined Hong Kong Market, and stated when the ownership of managerial is below $25 \%$ the disclosure of firms increased, which indicates that the interest between manager and shareholders is aligned and conflict reduces; but when the managerial ownership exceeds $25 \%$ the agency problem changes from vertical to horizontal, and the disclosure decreased (The managerial ownership in our sample is $24.73 \%$ ). The vertical agency problem refers to the principle and agent problem, while the horizontal refers to the conflict between large shareholding and small shareholdings.

This gives clarification for the problem statement in this study, which is the net effects of the horizontal and vertical agency problem. This paper's result shows positive impacts of managerial blockholders on the information asymmetry, and this implies that increase in managerial ownership creates horizontal agency problem more than vertical. Other than that, the high information asymmetry gap between managerial blockholders and individual small investor in stock market also contributed by the lower incentives and resources for small investors to monitor the firms (Attig et al., 2006). This lead to higher levels in the information asymmetry.

Our result shows institutional blockholders have no impact on information asymmetry. The result is inconsistent with prior studies Song and Zheng (2014), Rubin and Smith (2009), Shiri et al. (2016), ONeill (2003) and Omari et al. (2014) where all of them found a significant relationship. Yet, there are some studies found a similar result with ours, such as Chiang and Venkatesh (1988) and Iskrandani (2016). According to Demstz (1986), unlike insider, institutional blockholders hold a large portfolio of stock in different company which they do not really have the excess to the private information and even institutional do have the private information, they are bounded by legal constraint. So, Demstz is suggesting that institutional blockholders is similar to the public in informativeness, and they share the same information. However, the institutional investor does have more expertise and resources compared with individual small shareholders, which allow them to interpret more on the public disseminate information. Hence, this might be an explanation for the insignificant positive result that this paper found.

In short, the result also implies that the increase of institutional does not increase the information asymmetry as expected by the active monitoring hypothesis which hypothesised that institutional blockholders could monitor the firm better due to its higher incentives and increase the information asymmetry in the market. In addition, there are some researchers also states that an increase in institutional ownership will lead to more number of financial 
analyst following on the firms, which in turn reduce information asymmetry. But apparently, the result does not support this theory and predictions as there is no relationship for both variables.

Our result also shows there is no relationship between individual blockholders and information asymmetry. As mentioned in previous, based on literature review in empirical studies there is no exact agreed relationship for this relationship as most of the studies found different result. The result for this study is inconsistent with the studies of Brockman and Yan (2009), Ezazi, Sadeghisharif, Alipour and Amjadi. (2011), Che 2016 and others. There are also studies that consistent with this paper which the relationship is not found between individual ownership and information asymmetry such as Alzeaideen et al. (2014) and Fayomi et al. (2010). The insignificant of this variable might be caused by low level of individual blockholders in the data sample (the average of individual ownership is $4.76 \%$ ). The sample of this study consists of top 150 market capitalization firms in Malaysia, and in large market, the individual is usually less as the capital requirement is huge. Based on the result, it suggested that in Malaysia, the individual blockholder have no information advantage compared to small shareholders. Hence, it does not have any impact on information asymmetry.

Based on the result, the ownership concentration has no significant relationship with information asymmetry. The result is inconsistent with most of the studies such as Ni (2017), Dennis and Strickland (2009), Leuz and Verrecchia (2000) and Brockman and Yan (2009). In addition, Balsmeier and Czarnitzki (2017) found $U$ shape relationship and suggested that the ownership concentration's impact on information asymmetry is no monotomic. According to Shleifer and Vishny (1997) when ownership concentration is low, the information asymmetry will become very low and as the ownership concentration increases the information asymmetry increase as the blockholders monitoring roles increase. However, as the ownership becomes more and more concentrated it will, in turn, create larger information asymmetry due to divergence of interest and then the incentives to disclose information become less (Morck, Shleifer, \& Vishny, 1988). Hence, the inconsistent of this paper result and past research might be explained by this $U$ shaped relationship.

For control variables, result shows negative and significant impact of firm size on the information asymmetry, which means as the firm size increases the information asymmetry becomes lower. This result is consistent with the previous study, such as Dasti et al. (2014), Ali et al. (2010) and Alzeaideen and Al_Rawash (2014). The explanation for the significant negative result is firm size effects because the larger firms tend to have better corporate governance, disclosure quality, higher number of financial analyst following and also more attention from the public (Beeks \& Brown, 2006; Eng \& Mak, 2003). For trading volume, we found that higher trading volume tends to reduce bid-ask spread and increase stock volatility. The relationship is based on the rationale that when the information asymmetry is high, investor tends to trade less to avoid exploitation by informed trading. Empirically the study of Chae (2005) found that before the announcement where the information asymmetry is high the trading volume decrease as high as $15 \%$ and evidence that trading volume is negatively correlated with information asymmetry. The result from the study of Welker 
(1995) also shows that trading volume increase will lead to a decrease in bid-ask spread because of the decrease in informed trading and information asymmetry.

\section{Conclusion and Implication}

The study builds on a motivation to understand the effects of different type of blockholders identity and its concentration on the information asymmetry in the stock market. By examining 150 companies in Malaysia Main Market from 2011 to 2015, we found that the managerial blockholders do have significant positive impact on information asymmetry. This supports the agency theory on managerial large shareholdings and small shareholdings at the stock market; by giving an insight into the increase of managerial ownership might bring harm more than good. The dilemma here is when managerial ownership increase, the agentprincipal problem reduced, but the horizontal agency problem between managerial shareholder and individual small shareholders increase. For the institutional and individual blockholders, the findings suggest that there is no impact on the information asymmetry level in the Malaysia stock market. Hence, there is no privilege for these categories of blockholders on information advantageous.

Our study contributes to the literature about the relationship of ownership structure and information asymmetry in Malaysia, which provide an empirical result for Top 150 firms in Malaysia. We help in shedding the light between ownership identities and information asymmetry in Malaysia. It is important to understand the impact of ownership structure in Malaysia due to the different environment compared with other countries, whereby Malaysian firms have high ownership concentration. Information symmetry is an important factor for a country stock market development as it ensures the investor protection, pricing of stock, economic growth and stability of stock market. As mentioned in the background of study, the information asymmetry can cause disaster or financial crisis and eventually cause the loss of confidence of investor, and thus, it should not be neglected. Hence, it is crucial to identify the factors or determinant that might cause high information asymmetry. So, the policy can be implemented to overcome this problem and therefore achieve the desired outcome.

Our results may benefit investors such as institutional investors and retail investors in refining their investment strategy. With the understanding of information asymmetry, if the investors aim for low information asymmetry firms, then they can allocate their investment into firms that dominated by institutional investment company like mutual fund, investing company or others. Besides that, it also provides a guideline to the investors in deciding whether to invest in a company that has large shareholdings concentration. As discussed in the introduction, in Malaysia, there are a lot of insider trading activities, and most of the parties involve are managerial executives. Subsequently, we recommend that the investor protection and corporate transparency in Malaysia need to be improved as there is information asymmetry arises in the stock market. As the Chinese proverb says, we must know our enemies thoroughly before the winning. Hence, it is important for the investor to identify the possible factors that may affect their investment returns.

Based on the results, managerial blockholders will lead to high information asymmetry; this provides an indicator for Securities Commission and Ministry of Finance Malaysia. We suggest 
that the law and code should be developed and implement to allow better governance and disclosure on those firms with high managerial ownership. For instance, Securities Commission of Malaysia should focus the inspection on firms with high managerial ownership instead on individual or institutional to have more effective monitoring and governance.

\section{Limitations and Recommendation on Further Studies Direction}

The study on this topic can be difficult, especially in the Malaysia stock market compared to other countries. The first limitation is on the accuracy of the data collected. There is no database that consists the ownership information in Malaysia hence the data need to be manually-collected, and it might consist human error, bias and inaccurate, especially there is a lot of ambiguity, and unclear information in the annual report as the reporting ways of every firm might be very different. Directly, this affected the number of sample due to the complexity and tedious on collecting data which might cause an unclear impact, especially on the individual blockholders as the big variances in individual blockholders. There is also a limitation on this study which some of the types of ownerships is not included such as foreign institutional, local institutional, government and family.

From the limitation, it also provides some direction which future scholar should consider other types of blockholders as it might give another different result and more accurate result. Besides that, the sample size also can be increased as the relationship might change at different level of firm size. As in large firms, the ownership is dominated by mostly institutional blockholders, and in small firms, the ownership structure is dominated by managerial or individual blockholders. Furthermore, after considerate the possibilities of $U$ shape relationship on the ownership structure on information asymmetry the quadratic function also can be included in the studies which allow a clearer and exact picture on the effects of ownership. The granger causality also can be employed to determine the causal relationship. Lastly, the studies on this topic should be explored since there are not many studies have been done in Malaysia stock market.

\section{Acknowledgement}

The authors would like to thank Universiti Malaysia Sarawak (UNIMAS) for the special MyRA Funding with Project ID: F01/SpMYRA/1690/2018.

\section{References}

Akerlof, G. A. (1970). The market for "Lemons": Quality, Uncertainty and the market mechanism, Quarterly Journal of Economics, 84 (August 1970): 488-500.

Ali, S. M., Salleh, N. M., \& Hassan, M. S. (2010). Ownership structure and earnings management in Malaysian listed companies: the size effect. Asian Journal of Business and Accounting, 1(2).

Alzeaideen, K. A., \& Al_Rawash, S. Z. (2014). The effect of ownership structure on share price volatility of listed companies in Amman Stock Exchange. Research Journal of Finance and Accounting, 5(6), 192-201.

Amran, N. A., \& Ahmad, A. C. (2013). Effects of ownership structure on Malaysian companies performance. Asian Journal of Accounting and Governance, 4, 51-60.

Atkins, A. B., \& Dyl, E. A. (1997). Market structure and reported trading volume: NASDAQ versus the NYSE. Journal of Financial Research, 20(3), 291-304. 
Attig, N., Fong, W. M., Gadhoum, Y., \& Lang, L. H. (2006). Effects of large shareholding on information asymmetry and stock liquidity. Journal of Banking \& Finance, 30(10), 28752892.

Azzam, I. (2010). The impact of institutional ownership and dividend policy on stock returns and volatility: Evidence from Egypt. International Journal of Business, 15(4), 443.

Balsmeier, B., \& Czarnitzki, D. (2017). Ownership concentration, institutional development and firm performance in Central and Eastern Europe. Managerial and Decision Economics, 38(2), 178-192.

Barclay, M. J., \& Smith, C. W. (1995). The maturity structure of corporate debt. The Journal of Finance, 50(2), 609-631.

Beltran, D. O., \& Thomas, C. P. (2010). Could asymmetric information alone have caused the collapse of private-label securitization. FRB International Finance Discussion Paper, (1010).

Berle, A. A., \& Means, G. G. C. (1991). The Modern Corporation and private property. Transaction publishers.

Boujelbene, Y., \& Besbes, L. (2012). The Determinants of Information Asymmetry between Managers and Investors: A Study on Panel Data. IBIMA Business Review, 2012, 1.

Brockman, P., \& Yan, X. S. (2009). Block ownership and firm-specific information. Journal of Banking \& Finance, 33(2), 308-316.

Bursa Malaysia. (2016). Main market listing requirements. Retrieved from http://www.bursamalaysia.com/misc/system/assets/18385/listing_requirement_ma in_market_archive_290416.pdf

Chae, J. (2005). Trading volume, information asymmetry, and timing information. The Journal of Finance, 60(1), 413-442.

Chalermchatvichien, P., Jumroenvong, S., Jiraporn, P., Singh, M. (2014) The effect of bank ownership concentration on capital adequacy, liquidity, and capital stability. Journal of Finance Services Resource, 45, 219-240

Chen, C. J., \& Yu, C. M. J. (2012). Managerial ownership, diversification, and firm performance: Evidence from an emerging market. International Business Review, 21(3), 518-534.

Chen, S. S., \& Ho, K. W. (2000). Corporate diversification, ownership structure, and firm value: The Singapore evidence. International Review of Financial Analysis, 9(3), 315-326.

Chiang, R., \& Venkatesh, P. C. (1988). Insider holdings and perceptions of information asymmetry: A note. The journal of finance, 43(4), 1041-1048.

Choi, J. J., Sami, H., \& Zhou, H. (2010). The impacts of state ownership on information asymmetry: Evidence from an emerging market. China Journal of Accounting Research, 3, 13-50.

Claessens, S., Djankov, S., \& Lang, L. H. (2000). The separation of ownership and control in East Asian corporations. Journal of Financial Economics, 58(1), 81-112.

Coles, J. L., Lemmon, M. L., \& Meschke, J. F. (2012). Structural models and endogeneity in corporate finance: The link between managerial ownership and corporate performance. Journal of Financial Economics, 103(1), 149-168.

Cornell, B. (1981). The relationship between volume and price variability in futures markets. Journal of Futures Markets, 1(3), 303-316.

Demsetz, H., \& Lehn, K. (1985). The structure of corporate ownership: Causes and consequences. Journal of Political Economy, 93(6), 1155-1177. 
Dennis, P., \& Strickland, D. (2004). The determinants of idiosyncratic volatility. Unpublished working paper, University of Virginia.

Easley, D., \& O'hara, M. (1987). Price, trade size, and information in securities markets. Journal of Financial Economics, 19(1), 69-90.

Eng, L. L., \& Mak, Y. T. (2003). Corporate governance and voluntary disclosure. Journal of Accounting and Public Policy, 22(4), 325-345.

Ettredge, M., Johnstone, K., Stone, M., \& Wang, Q. (2011). The effects of firm size, corporate governance quality, and bad news on disclosure compliance. Review of Accounting Studies, 16(4), 866-889.

Ezazi, M. S., Sadeghisharif, S. J., Alipour, M., \& Amjadi, H. (2011). The Effect of Ownership Structure on Share Price Volatility of Listed Companies in Tehran Stock Exchange: An Empirical Evidence of Iran. International journal of business and social science, 2(5163169).

Fama, E. F. (1965). The behavior of stock-market prices. The journal of Business, 38(1), 34105.

Fama, E. F., \& French, K. R. (1992). The cross-section of expected stock returns. The Journal of Finance, 47(2), 427-465.

Fama, E. F., \& Jensen, M. C. (1983). Separation of ownership and control. The Journal of Law \& Economics, 26(2), 301-325.

Finnerty, J. E. (1976). Insiders and market efficiency. The Journal of Finance, 31(4), 1141-1148.

Gedajlovic, E., \& Shapiro, D. M. (2002). Ownership structure and firm profitability in Japan. Academy of Management Journal, 45(3), 565-575.

Gillan, S., \& Starks, L. T. (2003). Corporate governance, corporate ownership, and the role of institutional investors: A global perspective. Journal of Applied Finance, 13(2).

Glosten, L. R., \& Harris, L. E. (1988). Estimating the components of the bid/ask spread. Journal of Financial Economics, 21(1), 123-142.

Glosten, L. R., \& Milgrom, P. R. (1985). Bid, ask and transaction prices in a specialist market with heterogeneously informed traders. Journal of financial economics, 14(1), 71-100.

Goergen, M., \& Renneboog, L. (2001). Investment policy, internal financing and ownership concentration in the UK. Journal of Corporate Finance, 7(3), 257-284.

Gordon, L. A., \& Pound, J. (1993). Information, Ownership Structure, and Shareholder Voting: Evidence from Shareholder-Sponsored Corporate Governance Proposals. The Journal of Finance, 48(2), 697-718.

Gul, F. A., Kim, J. B., \& Qiu, A. A. (2010). Ownership concentration, foreign shareholding, audit quality, and stock price synchronicity: Evidence from China. Journal of Financial Economics, 95(3), 425-442.

Harris, L. (1987). Transaction data tests of the mixture of distributions hypothesis. Journal of Financial and Quantitative Analysis, 22(02), 127-141.

Heflin, F., \& Shaw, K. W. (2000). Blockholder ownership and market liquidity. Journal of Financial and Quantitative Analysis, 35(4), 621-633.

Ho, P. and Taylor, G., 2014. The Impact of Governance and Ownership Structure on Disclosure Patterns Transcending Major Regulatory Change in Malaysia. Corporate Ownership \& Control. 12 (1): pp. 114-125

Ho, W. F. (2016). Bearing down on insider trading. The Star Online. Retrieved from http://www.thestar.com.my/news/nation/2016/03/20/bearing-down-on-insidertrading/ 
Ishak, Z., \& Napier, C. (2006). Expropriation of minority interests and corporate diversification in Malaysia. Asian Academy of Management Journal of Accounting and Finance, 2(1), 85-113.

Iskandrani, M. (2016). Market liquidity, analysts coverage, and ownership concentration: evidence from ASE. International Journal of Commerce and Finance, 2(1), 14.

Jankensgård, H., \& Vilhelmsson, A. (2015). Ownership Determinants of Stock Return Volatility. Available at SSRN, 2599488.

Jennings, W., Schnatterly, K., \& Seguin, P. (2002). Institutional ownership, information and liquidity. Advances in Financial Economics, 7, 41-72.

Jensen, M. C., \& Meckling, W. H. (1976). Theory of the firm: Managerial behavior, agency costs and ownership structure. Journal of financial economics, 3(4), 305-360.

Jensen, M. C., \& Murphy, K. J. (1990). Performance pay and top-management incentives. Journal of Political Economy, 225-264.

Jiang, H., Habib, A., \& Hu, B. (2011). Ownership concentration, voluntary disclosures and information asymmetry in New Zealand. The British Accounting Review, 43(1), 39-53.

Kadir, R., \& Muhamad, S. (2012). Insider trading in Malaysia; towards an improved regulation. International Journal of Law and Management, 54(1), 78-86.

Karpoff, J. M. (1987). The relation between price changes and trading volume: A survey. Journal of Financial and Quantitative Analysis, 22(01), 109-126.

Kidwel, R. E., \& Nygaard, A. (2010). The Dual-Agency Problem Reconsidered: A Strategic Deviance Perspective on the Franchise Form of Organizing. CCGR Working Paper, $(1 / 2010)$

Kim, O., \& Verrecchia, R. E. (1991). Trading volume and price reactions to public announcements. Journal of Accounting Research, 302-321.

Kini, O., \& Mian, S. (1995). Bid-ask spread and ownership structure. Journal of Financial Research, 18(4), 401-414.

Koke, J. F. (1999). New evidence on ownership structures in Germany. Centre for European Economic Research Working Paper, (99-60).

Kothare, M. (1997). The effects of equity issues on ownership structure and stock liquidity: A comparison of rights and public offerings. Journal of Financial Economics, 43(1), 131148.

Kyle, A. S. (1985). Continuous auctions and insider trading. Econometrica: Journal of the Econometric Society, 1315-1335.

Leaño, M., \& Pedraza, A. (2016). Informed trading in business groups, ownership concentration, and market liquidity. World Bank Policy Research Working paper.7688.

Lee, C., \& Swaminathan, B. (2000). Price momentum and trading volume. The Journal of Finance, 55(5), 2017-2069.

Lee, P. M., \& O'neill, H. M. (2003). Ownership structures and R\&D investments of US and Japanese firms: Agency and stewardship perspectives. Academy of Management Journal, 46(2), 212-225.

Lemmon, M. L., \& Lins, K. V. (2003). Ownership structure, corporate governance, and firm value: Evidence from the East Asian financial crisis. The Journal of Finance, 58(4), 14451468.

Leuz, C., \& Verrecchia, R. E. (2000). The economic consequences of increased disclosure (digest summary). Journal of accounting research, 38(3), 91-124. 
Lim, K. P. (2008). Sectoral efficiency of the Malaysian stock market and the impact of the Asian financial crisis. Studies in Economics and Finance, 25(3), 196-208.

Lin, J. C., Sanger, G. C., \& Booth, G. G. (1995). Trade size and components of the bid-ask spread. Review of Financial Studies, 8(4), 1153-1183.

Ling, P. S., \& Abdul-Rahim, R. (2016). Efficiency of Malaysian stock market: a revisit based on analysts' recommendations. Geografia: Malaysian Journal of Society and Space, 12(2), 1-14.

Lo, A. W., \& Wang, J. (2000). Trading volume: definitions, data analysis, and implications of portfolio theory. Review of Financial Studies, 13(2), 257-300.

Mak, Y. T., \& Li, Y. (2001). Determinants of corporate ownership and board structure: evidence from Singapore. Journal of Corporate Finance, 7(3), 235-256.

McCahery, J. A., Sautner, Z., \& Starks, L. T. (2016). Behind the scenes: The corporate governance preferences of institutional investors. The Journal of Finance, 71(6), 29052932.

McKinnon, J. L., \& Dalimunthe, L. (1993). Voluntary disclosure of segment information by Australian diversified companies. Accounting \& Finance, 33(1), 33-50.

Mintzberg, H. (1983). Power in and around organization. Englewood Cliff, NJ: Prentice Hall

Mishra, D. P., Heide, J. B., \& Cort, S. G. (1998). Information asymmetry and levels of agency relationships. Journal of Marketing Research, 277-295.

Modigliani, F., \& Miller, M. H. (1963). Corporate income taxes and the cost of capital: a correction. The American Economic Review, 53(3), 433-443.

Morck, R., Shleifer, A., \& Vishny, R. W. (1988). Management ownership and market valuation. Journal of Financial Economics, 20, 293-315.

Munir, Q., \& Mansur, K. (2009). Is Malaysian stock market efficient? Evidence from threshold unit root tests. Economics Bulletin, 29(2), 1359-1370.

Mustapha, M., \& Ahmad, C. A. (2011). Agency theory and managerial ownership: evidence from Malaysia. Managerial Auditing Journal, 26(5), 419-436.

$\mathrm{Ni}, \mathrm{W}$. (2017). Research on ownership structure and stock price fluctuation. Advances in Computer Science Research (ACSR), volume 61

Omari, J., Fazlzadeh, A. \& Nahidi M. N. (2014). The relationship between ownership concentration and information asymmetry considering level of voluntary disclosure of firms listed in Tehran Stock Exchange. Research Journal of Recent Sciences, 3(4), 40-46

Paramanantham, N. S., Ting, I. W. K., \& Kweh, Q. L. (2018). Ownership concentration and debt structure: Evidence from top 100 PLCs in Malaysia. Institutions and Economies.

Petersen, C., \& Plenborg, T. (2006). Voluntary disclosure and information asymmetry in Denmark. Journal of International Accounting, Auditing and Taxation, 15(2), 127-149.

Porta, R., Lopez-de-Silanes, F., \& Shleifer, A. (1999). Corporate ownership around the world. The Journal of Finance, 54(2), 471-517.

Prado, M. P., Saffi, P. A., \& Sturgess, J. (2016). Ownership structure, limits to arbitrage, and stock returns: Evidence from equity lending markets. Review of Financial Studies, hhw058.

Prigge, S. (2007). The performance of shareholder influence measures: An empirical assessment of share in votes, Banzhaf Index, and Shapley-Shubik Index. Banzhaf Index, and Shapley-Shubik Index (September 2007).

Puelz, R., \& Snow, A. (1994). Evidence on adverse selection: Equilibrium signaling and crosssubsidization in the insurance market. Journal of Political Economy, 236-257. 
Rubin, A. (2007). Ownership level, ownership concentration and liquidity. Journal of Financial Markets, 10(3), 219-248.

Rubin, A., \& Smith, D. R. (2009). Institutional ownership, volatility and dividends. Journal of Banking \& Finance, 33(4), 627-639.

Samaha, K., \& Dahawy, K. (2010). Factors influencing corporate disclosure transparency in the active share trading firms: An explanatory study. Research in Accounting in Emerging Economies, 10(1), 87-118.

Securities Commission Malaysia. (2015). The annual report, 2015. Retrieved from https://www.sc.com.my/post_archive/2015-annual-report/

Securities Commission Malaysia. (2016). Acts and Regulations. Retrieved from https://www.sc.com.my/legislation-guidelines/acts-regulations/

Shalit, S. S., \& Sankar, U. (1977). The measurement of firm size. The Review of Economics and Statistics, 290-298.

Shiri, M. M., Salehi, M., \& Radbon, A. (2016). A Study of Impact of Ownership Structure and Disclosure Quality on Information Asymmetry in Iran. Vikalpa, 41(1), 51-60.

Shleifer, A., \& Vishny, R. W. (1997). A survey of corporate governance. The Journal of Finance, 52(2), 737-783.

Song, X., \& Zheng, W. (2014). Ownership structure, stock volatility and analyst independence: evidence from China. China Finance Review International, 4(2), 187-208.

Tam, O. K., \& Tan, M. G. S. (2007). Ownership, governance and firm performance in Malaysia. Corporate Governance: An International Review, 15(2), 208-222.

The Companies Commission of Malaysia. (2016). Companies act 1965 (Revised-1973).

Retrieved from https://www.ssm.com.my/acts/fscommand/CompaniesAct.htm

Wahab, E. A., Zain, M. M., James, K. and Haron, H. (2009), "Institutional investors, political connection and audit quality in Malaysia", Accounting Research Journal, Vol. 22 No. 2, pp. 167-195.

Wang, A. W., \& Zhang, G. (2009). Institutional ownership and credit spreads: An information asymmetry perspective. Journal of Empirical Finance, 16(4), 597-612.

Welker, M. (1995). Disclosure policy, information asymmetry, and liquidity in equity markets. Contemporary Accounting Research, 11(2), 801-827.

$\mathrm{Xu}, \mathrm{X} .$, \& Wang, Y. (1999). Ownership structure and corporate governance in Chinese stock companies. China Economic Review, 10(1), 75-98.

Zhou, D. (2011). Ownership structure, liquidity, and trade informativeness. Journal of Finance and Accountancy, 6, 1. 